\title{
The Latent Nature of Global Information Warfare
}

\author{
Luciano Floridi
}

Published online: 29 July 2014

(C) Springer Science+Business Media Dordrecht 2014

Information has always been at the core of conflicts. When Napoleon planned to invade Italy, he duly upgraded the first telegraph network in the world, the French "semaphore". He famously remarked that "an army marches on its stomach," but he also knew that the same army acted on information. As Von Clausewitz once stated "by the word 'information' we denote all the knowledge which we have of the enemy and his country; therefore, in fact, the foundation of all our ideas of actions [in war]."1 This is why the radar, the computer, the satellite, the GPS system, and the Internet were initially developed as military technologies, while unmanned vehicles are becoming a reality thanks to DARPA. The difference between then and now is that information warfare is acquiring kinetic aspects unknown to past generations. Information has become a weapon because the targets too have become informational. The phenomenon is well known. Today, those who live by the digit may die by the digit. This much is clear. The question is how we should understand such a macroscopic transformation. ${ }^{2}$

A popular interpretation is rooted in the eighties. Simulacra and Simulation, Jean Baudrillard's book on the relationship between the real and the symbolic, was published in $1981{ }^{3}$ It was required reading for the actors in The Matrix, where it appears in the first episode. WarGames, the American Cold War science-fiction film, became a box office success in 1983. Both Simulacra and Simulation and WarGames suggested looking at the role of information in conflicts in terms of an increasing process of simulation, virtualization, and gamification. This was understandable but, today, it has also become misleading.

To understand why, consider your bed in your house. This may be the actual object in which you sleep. Let's define that the system. Or it may be an idea of your bed, say what you have in mind when you are at work. Let's define that the model. When we treat something as real, we expect the system and the model to be correctly related.

\footnotetext{
${ }^{1}$ I am very grateful to Mariarosaria Taddeo for this citation and for our fruitful collaboration on a 2-year project about the ethics of information warfare, Marie Curie Fellowship Grant, FP7-PEOPLE-2009-IEF see now (Floridi and Taddeo 2014).

${ }^{2}$ I have discussed the new nature of conflicts in (Floridi 2014).

${ }^{3}$ The French original is (Baudrillard 1981), for an English translation see (Baudrillard 1994).

L. Floridi $(\bowtie)$

Oxford Internet Institute, University of Oxford, 1 St Giles, Oxford OX1 3JS, UK

e-mail: luciano.floridi@oii.ox.ac.uk
} 
When this relation does not work correctly, we make mistakes, e.g., we bump into the bed (the system) at night because we think it (the model) is elsewhere. The virtual is not real, but it is not a mistake either. It is rather a model without a corresponding system. The engineer designing a bed is working with a model (blueprint) to which nothing yet in the world corresponds, it is a "virtual" bed, like the shadow of an object without its corresponding object. You know it is virtual because you cannot sleep in it, no more than you could sleep in Plato's idea of the bed. One of the problems with Kant is that, when you lie in bed, you lie in the noumenal not just in the phenomenal bed, whatever that may be in itself. To change example a little: when you eat an apple, you eat both the system (whatever the noumenal apple in itself may be, in Kant's terminology) and the model (whatever the phenomenal apple is perceived to be by you when eating it).

Notice now that the decoupling between system and model cuts both ways. There is the opposite case in which, instead of there being a model without its system (the virtual), there is a system without its model. This is the case in which the representable remains unrepresented. Imagine an object without its shadow, like Peter Pan. There is no technical word for this, so let me use latent, in the original Latin sense of concealed or unknown. What there is in the world is either real (system + model), virtual (only the model), or latent (only the system). The world is full of latent things, systems that remain or are meant to remain below the threshold of the observable. The operations of the NSA were latent until Snowden disclosed them. Only then did they become real for all of us.

Let us return to the nature of information warfare. In the past, war has always and only been real, in the system + model sense, like the bed in which you sleep and the apple you eat. The hard facts of war were inevitably accompanied by their informational shadows: the human shouting, the smell of horses, the sounds of trumpets in battles, the rhythm of machineguns, the pitched whistles of bombs falling from the sky, the smell of napalm, the marks left by the tanks' tracks. For a short time, in the eighties, passive mass media and digital consumerism made us mistakenly think that war could be experienced by the public as virtual: a televised or computerized game, involving only representations to which nothing corresponded, like shadows without objects, simulacra in Baudrillard's terminology. Thus, in 1991, ${ }^{4}$ Baudrillard argued in The Gulf War Did Not Take Place that the hi-tech fighting on the American side during the first Gulf War had transformed a conflict into propaganda and mass-mediated experience. The analysis was correct both in perceiving a difference and in identifying that difference in the decoupling between the system and the model. But it was wrong in selecting models as the new battlefields. Global information warfare is not virtual. It is mostly latent, that is, it is in the world but not experienced as part of the world. It is a war without shadows. You cannot see it, and cannot hear it, it silently happens everyday, can hit anyone anywhere, and we can all be its unaware victims. Take for instance distributed denial-of-service attacks. According to Arbor Networks, more than 2,000 of DDoS occur worldwide every day. ${ }^{5}$ Their number is increasing and more and more countries are involved that are not officially at war with each other. Similar attacks are very cheap. According to TrendMicro Research a week-long DDoS attack, capable of taking a small organization offline, can cost as little as $\$ 150$ in the

\footnotetext{
${ }^{4}$ The book (Baudrillard 1995) begun as a collection of three essays published in Libération and in The Guardian between January and March 1991.

${ }^{5}$ Source: http://www.digitalattackmap.com
} 
underground market. This is just an example. Conflicts in the infosphere-not just DDoS attacks, but also trade wars, currency wars, patent wars, marketing wars, and other silent forms of informational battles to win hearts, minds, and wallets - are increasingly neither real nor virtual, but latent to most of their victims. They are nonetheless dangerous and wasteful. They require special interfaces to be perceived. They will require a special sensitivity to be eradicated.

\section{References}

Baudrillard, J. (1981). Simulacres et simulation, Débats. Paris: Éditions Galilée.

Baudrillard, J. (1994). Simulacra and simulation. Ann Arbor: University of Michigan Press.

Baudrillard, J. (1995). The gulf war did not take place. Bloomington: Indiana University Press.

Floridi, L. (2014). The fourth revolution: how the infosphere is reshaping human reality. Oxford: Oxford University Press.

Floridi, L., \& Taddeo, M. (Eds.). (2014). The ethics of information warfare. New York: Springer. 